Jurnal Akuntansi dan Keuangan (JAK)

Volume 6, No. 2 Oktober Tahun 2021

Page: 243 - 256

http://ojs.uho.ac.id/index.php/jak-uho/issue/archive

e-ISSN: 2088-4656

\title{
PENGARUH PENGGUNAAN INFORMASI AKUNTANSI \\ TERHADAP KINERJA USAHA, MIKRO, KECIL, DAN MENENGAH (UMKM) \\ DI KOTA KENDARI
}

\author{
Safaruddin $^{1}$, Muntu Abdullah ${ }^{2}$, Irda Zulhijayanti Syahrir ${ }^{3}$ \\ Jurusan Akuntansi Fakultas Ekonomi dan Bisnis Universitas Halu Oleo Kendari \\ Sulawesi Tenggara
}

\begin{abstract}
ABSTRAK
Penelitian ini bertujuan untuk mengetahui dan menganalisis pengaruh penggunaan informasi akuntansi terhadap kinerja usaha mikro, kecil, dan menengah (UMKM) di Kota Kendari. Sampel pada penelitian ini menggunakan teknik purposive sampling, dan pengukuran sampel menggunakan rumus slovin, dari penentuan sampel diperoleh 50 pengusaha. Metode pengumpulan data menggunakan kuesioner. Analisis data menggunakan metode statistik deskriptif dan analisis regresi sederhana. Hasil penelitian ini menunjukkan bahwa Penggunaan Informasi Akuntansi berpengaruh signifikan terhadap Kinerja Usaha Mikro, Kecil, dan Menengah (UMKM) di Kota Kendari di bidang fashion (pakaian jadi). Kesimpulannya bahwa penggunaan informasi akuntansi dapat digunakan untuk meningkatkan kinerja usaha mikro, kecil, dan menengah (UMKM). Bila manajemen mampu untuk mengoptimalkan penggunaan informasi akuntansi secara signifikan maka dengan demikian kinerja usaha mereka akan meningkat signifikan.
\end{abstract}

Kata Kunci: Penggunaan Informasi Akuntansi, Kinerja Usaha,UMKM

\section{ABSTRACT}

This study aims to determine and analyze the effect of accounting information use on the performance of micro, small and medium enterprises (MSMEs) in Kendari City. The sample in this study used purposive sampling technique, and sample measurement using the Slovin formula, from the determination of the sample obtained 50 entrepreneurs. The data collection method used a questionnaire. Data analysis used descriptive statistical methods and simple regression analysis. The results of this study indicate that the use of accounting information has a significant effect on the performance of Micro, Small and Medium Enterprises (MSMEs) in Kendari City in the fashion sector (apparel). The conclusion is that the use of accounting information can be used to improve the performance of micro, small and medium enterprises (MSMEs). If management is able to significantly optimize the use of accounting information, then their business performance will increase significantly.

Keywords: Use of Accounting Information, Business Performance, MSMEs 
Jurnal Akuntansi dan Keuangan (JAK)

Volume 6, No. 2 Oktober Tahun 2021

Page: 243 - 256

http://ojs.uho.ac.id/index.php/jak-uho/issue/archive

e-ISSN: 2088-4656

\section{PENDAHULUAN}

Pembangunan perekonomian di Indonesia umumnya berdasarkan pada ekonomi kerakyatan, yang dapat dilihat pada sektor usaha mikro, kecil dan menengah (UMKM). Sektor ini mempunyai peranan yang cukup besar dalam perekonomian nasional maupun daerah. usaha mikro, kecil dan menengah (UMKM) merupakan salah satu bentuk usaha yang paling banyak dijalani oleh pengusaha di Indonesia. Hal ini dikarenakan pengelolaannya yang tidak sulit dan juga mudah untuk dilakukan oleh pihak dari kalangan manapun serta tidak membutuhkan biaya yang besar. Tidak hanya itu keterpurukan perekonomian Indonesia akibat krisis moneter, menjadikan usaha kecil sebagai sektor andalan yang paling diminati oleh berbagai kalangan.

Di balik kekuatan UMKM dalam menahan gejolak krisis ekonomi, terdapat kasus yang sering dialami oleh para pengusaha kecil dan menengah dalam mengembangkan usahanya. Permasalahan yang terjadi muncul karena UMKM susah buat mengakses sumber-sumber ekonomi yang ada, semacam aktivitas yang menyangkut manajemen, penciptaan serta pemasaran, hukum, dan keuangan (Tanjung, 2017). Tujuan pemberdayaan UMKM dalam UU No. 20 Tahun 2008 adalah meningkatkan serta menumbuhkan kemampuan UMKM jadi usaha yang tangguh serta mandiri, oleh sebab itu telah sepatutnya para pengusaha mencermati masalah-masalah yang ada.

Mayoritas UMKM yang terdapat di daerah Kota Kendari tidak memakai sistem informasi akuntansi secara rinci disebabkan banyak aspek lain yang menjadikan kinerja usaha. Namun tidak menutup kemungkinan penggunaan sistem informasi akuntansi juga berpengaruh terhadap kinerja usaha serta mengingat pentingnya peranan penggunaan informasi akuntansi bagi sebuah UMKM, khususnya untuk para pemilik usaha ataupun manajemen perusahaan dalam mengetahui berapa besar biaya-biaya yang dikeluarkan serta pemasukan yang diperoleh sepanjang periode tertentu, sehingga bisa merancang serta menegendalikan besarnya biaya-biaya yang dikeluarkan serta pemasukan yang diperoleh buat periode yang hendak tiba.

Pertumbuhan ekonomi Kota Kendari, peran UMKM sangat menentukan karena UMKM merupakan kelompok usaha yang memiliki jumlah paling besar. Selain itu, kelompok ini terbukti mampu bertahan terhadap berbagai macam goncangan krisis ekonomi serta UMKM juga menciptakan peluang kerja yang cukup besar, sehingga membantu upaya mengurangi pengangguran.

Dalam hal kuantitas, jumlah UMKM di Kota Kendari, antara lain: (1) Usaha Mikro sebanyak 40.752, (2) Usaha Kecil sebanyak 1.160, dan (3) Usaha Menengah 41.998. Dapat disimpulkan jumlah UMKM yang telah digolongkan dalam usaha mikro, usaha keil dan usaha menengah yang terdaftar di tahun 2019. Jumlah UMKM yang ada di Kota saat ini yang disebabkan oleh munculnya UMKM-UMKM baru dan tidak jarang juga UMKM berhenti menjalankan usahanya sehingga menyebabkan meningkat dan berkurang jumlah UMKM yang ada di Kota Kendari. Akan tetapi dibalik pertumbuhan UMKM yang meningkat dan berkurang di Kota Kendari terdapat beberapa 
Jurnal Akuntansi dan Keuangan (JAK)

Volume 6, No. 2 Oktober Tahun 2021

Page: 243 - 256

http://ojs.uho.ac.id/index.php/jak-uho/issue/archive

e-ISSN: 2088-4656

permasalahan yang dihadapi oleh UMKM, yaitu diantaranya masih rendahnya produktivitas UMKM.

Melihat fenomena bahwa praktek akuntansi pada UMKM masih rendah, namun sebenarnya informasi akuntansi bisa jadi dasar untuk pengambilan keputusan bisnis dalam rangka menggapai kinerja usaha dalam kenyataannya, mayoritas pengusaha kecil di Indonesia tidak menyelenggarakan serta menggunakan informasi akuntansi dalam pengelolaan usahanya.

Berdasarkan kasus tersebut, pencatatan akuntansi dapat membantu pelaku UMKM untuk mulai menertibkan pencatatan administrasi keuangan mereka. Selain itu, manfaat dari pencatatan keuangan untuk pihak kreditor atau pihak lain yang turut berfungsi dalam pengelolaan usaha adalah dapat melihat pertumbuhan kinerja usaha serta bisa mengestimasi kinerja usaha di masa yang akan datang, sehingga pengusaha UMKM harus dibiasakan untuk menyusun serta menyajikan laporan keuangan bagaikan salah satu upaya pengembangan usahanya.

Teori motivasi mempengaruhi dalam pengambilan keputusan karena penggunaan informasi akuntansi dalam suatu usaha atau bisnis, motivasi secara umum timbul apabila pelaku kegiatan mengetahui kebutuhan dan kekurangannya dan kemudian mencari cara untuk memuaskan kebutuhannya itu. Kebutuhan informasi yang didapat tersebut akan mempengaruhi pengambilan keputusan bisnis. Stakeholder Theory relevan untuk menjelaskan penggunaan informasi akuntansi pada UMKM. Stakeholder memiki hak untuk mendapatkan informasi terkait aktifitas-aktifitas perusahaan yang mempengaruhi mereka. Semakin kuat hubungan stakeholder, maka akan semakin baik bisnis perusahaan. Tanpa dukungan dari pihak-pihak yang berkepentingan maka perusahaan tidak bisa hidup terus-menerus, oleh karena itu penggunaan informasi akuntansi pada perusahaan merupakan cara untuk mengelola kepercayaan pihak-pihak yang berkepentingan agar menghasilkan hubungan yang harmonis antara perusahaan dengan stakeholdernya.

Informasi akuntansi yang rendah akan menyebabkan usaha yang dijalankan akan mengalami kegagalan manajemen sehingga sulit untuk para pelaku usaha dalam menentukan kebijakan apa yang akan diambil. Beberapa penelitian terkait dengan pengaruh penggunaan informasi akuntansi terhadap kinerja usaha mikro, kecil, dan menengah (UMKM) juga pernah dilakukan oleh Nurhikmah dan Djauhar (2019), T.Irzal dan Mulia (2019), Kadek dan Agung (2014) yang menunjukkan hasil penelitian bahwa penggunaan informasi akuntansi berpengaruh terhadap kinerja UMKM. Tetapi berbeda dengan penelitian yang dilakukan oleh Novia dan Siti (2019) yang menunjukkan informasi akuntansi tidak berpengaruh terhadap keberhasilan UKM, berdasarkan pengamatan yang dilakukan peneliti ketika mengambil data dari responden, rata-rata pelaku usaha tidak terlalu memperhatikan hal-hal yang menyangkut dengan penggunaa informasi akuntansi hal ini dikarenakan masih banyak yang kurang paham dengan penggunaan informasi akuntansi. 
Jurnal Akuntansi dan Keuangan (JAK)

Volume 6, No. 2 Oktober Tahun 2021

Page: 243 - 256

http://ojs.uho.ac.id/index.php/jak-uho/issue/archive

e-ISSN: 2088-4656

Begitu pentingnya peranan penggunaan informasi akuntansi terhadap kinerja usaha mikro, kecil, dan menengah (UMKM) di Kota Kendari. Penelitian ini bertujuan untuk mengetahui dan menganalisis pengaruh penggunaan informasi akuntansi terhadap kinerja usaha mikro, kecil, dan menengah. Hasil penelitian ini diharapkan dapat bermanfaat dan berguna bagi perusahaan sebagai masukan untuk untuk lebih meningkatkan kinerja usahanya dan bagi peneliti selanjutnya diharapkan menjadi bahan referensi untuk melakukan penelitian selanjutnya.

\section{LANDASAN TEORI DAN HIPOTESIS}

\section{A. Penggunaan Informasi Akuntansi}

Penggunaan merupakan dasar dari kata "guna" yang dalam KBBI berarti proses, cara, atau perbuatan menggunakan sesuatu. Penggunaan informasi akuntansi merupakan suatu perbuatan dalam menggunakan informasi akuntansi yang ada di dalam perusahaan.

Menurut Belkaoui (2000:39) Informasi akuntansi digolongkan menjadi tiga jenis yaitu:

1. Informasi Operasi

Informasi operasi ini menyediakan data mentah bagi informasi akuntansi keuangan dan informasi akuntansi manajemen. Informasi operasi yang terdapat didalam sebuah perusahaan manufaktur antara lain: informasi produksi, informasi pembelian dan pemakaian bahan baku, informasi penggajian, informasi penjualan.

2. Informasi Akuntansi Manajemen

Informasi akuntansi yang khusus ditujukan untuk kepentingan manajemen disebut informasi akuntansi manajemen. Informasi ini digunakan dalam tiga fungsi manajemen, yaitu: (1) perencanaan; (2) implementasi; (3) pengendalian. Informasi akuntansi manajemen ini dihasilkan oleh sistem pengolahan informasi keuangan yang disebut akuntansi manajemen.

3. Informasi Akuntansi Keuangan

Informasi akuntansi keuangan digunakan baik oleh manajer maupun pihak eksternal perusahaan, dengan tujuan untuk menyediakan informasi yang menyangkut posisi keuangan, kinerja serta perubahan keuangan suatu perusahaan yang bermanfaat bagi sejumlah besar pemakai dalam pengambilan keputusan ekonomi.

Holmes dan Nicholls (1988) mengklasifikasikan informasi akuntansi dalam tiga jenis yang berbeda menurut manfaatnya bagi para pemakai, yaitu:

1. Statutory accounting information, merupakan informasi akuntansi yang harus disiapkan sesuai dengan peraturan yang ada.

2. Budgetary information, yaitu informasi akuntansi yang disajikan dalam bentuk anggaran yang berguna bagi pihak internal dalam perencanaan, penilaian dan pengambilan keputusan. 
Jurnal Akuntansi dan Keuangan (JAK)

Volume 6, No. 2 Oktober Tahun 2021

Page: 243 - 256

http://ojs.uho.ac.id/index.php/jak-uho/issue/archive

e-ISSN: 2088-4656

3. Additional accounting information, yaitu informasi akuntansi lain yang disiapkan perusahaan guna meningkatkan efektifitas pengambilan keputusan manajer.

\section{B. Akuntansi}

Menurut Suwardjono (2014) mendefinisikan akuntansi adalah "Proses pengidentifikasian, pengesahan, pengukuran, pengakuan, penggabungan, pengklarifikasian, peringkasan, dan penyajian data keuangan dasar (bahan olah akuntansi)nyang terjadi dari kejadian-kejadian, transaksi-transaksi, atau kegiatan operasi suatu unit organisasi dengan cara tertentu untuk menghasilkan informasi yang relevan bagi pihak yang berkepentingan”. Menurut Warren, dkk (2017) mendefinisikan "Akuntansi adalah sistem informasi yang menyediakan laporan untuk para pemangku kepentingan mengenai aktivitas ekonomi dan kondisi perusahaan.

Berdasarkan definisi diatas, dapat disimpulkan akuntansi merupakan proses, pengesahan, pengukuran, pengakuan, pengklarifikasian, penggabungan, peringkasan, dan penyajian data keuangan untuk menyediakan laporan untuk para pemangku kepentingan mengenai aktivitas ekonomi dan kondisi perusahaan yang membutuhkan hal tersebut.

Hall (2009) dalam bukunya menjelaskan bahwa fungsi akuntansi adalah untuk mengelola sumber daya informasi keuangan perusahaan. Fungsi akuntansi mempunyai dua peranan penting dalam pemrosesan transaksi, yaitu:

a. Akuntansi mencatat serta menangkap sesuatu yang mempengaruhi keuangan dari berbagai transaksi perusahaan. Pembelian persediaan serta pengiriman barang jadi ke pelanggan merupakan sebagian dari kegiatan yang mempengaruhi keuangan perusahaan.

b. Akuntansi berfungsi untuk mendistribusikan informasi mengenai transaksi kepada personel operasional untuk mengkoordinasikan tugas-tugas penting mereka. Aktifitas-aktifitas akuntansi yang berkaitan langsung dengan operasi bisnis seperti pengendalian persediaan, penggajian, penagihan, dll.

\section{Usaha Mikro, Kecil, dan Menengah (UMKM)}

Berdasarkan definisi UMKM menurut UU No. 20 Tahun 2008, dapat disimpukan usaha yang dimiliki oleh perorangan maupun badan usaha akan diklasifikasikan berdasarkan kriteria-kriteria tertentu untuk mengetahui peningkatan perkembangan usaha dan terkait dengan UMKM lebih berfokus untuk menghasilkan produk berdasarkan jenis usahanya. Berdasarkan Undang-Undang No. 20 Pasal 1 Tahun 2008 tersebut, kriteria UMKM dapat dibagi berdasarkan kepemilikan aset dan omzet perusahaan yang disajikan dalam Tabel 1

Tabel 1

Kriteria UMKM

\begin{tabular}{|c|l|l|l|}
\hline \multirow{2}{*}{ No } & & \multicolumn{2}{|c|}{ Kriteria } \\
\cline { 3 - 4 } & & \multicolumn{1}{|c|}{ Aset (Rp) } & Omzet (Rp) \\
\hline 1 & Usaha Mikro & $<50$ Juta & $<300$ Juta \\
\hline
\end{tabular}


Jurnal Akuntansi dan Keuangan (JAK)

Volume 6, No. 2 Oktober Tahun 2021

Page: 243 - 256

http://ojs.uho.ac.id/index.php/jak-uho/issue/archive

e-ISSN: 2088-4656

\begin{tabular}{|l|l|l|l|}
\hline 2 & Usaha Kecil & $>50$ Juta - 500 Juta & >300 Juta - 2,5 Miliar \\
\hline 3 & Usaha Menengah & >500 Juta - 10 Miliar & $>2,5$ Miliar - 50 Miliar \\
\hline
\end{tabular}

Sumber: UU No. 20 Pasal 1 Tahun 2008

\section{Kinerja Usaha}

Kinerja adalah suatu gambaran tentang kondisi suatu perusahan yang dianalisis dengan alat-alat analisis keuangan sehingga dapat diketahui baik atau buruknya keadaan keuangan perusahaan yang mencerminkan prestasi kerja dalam waktu tertentu. Pada dasarnya sebuah sistem informasi Akuntansi dapat menambah nilai bagi UMKM dengan, Meningkatkan efisiensi UMKM, meningkatkan kualitas UMKM, memberikan informasi yang tepat waktu dan dapat dipercaya untuk mengambil keputusan, dapat meningkatkan keunggulan kompetitif UMKM dan dapat memperbaiki komunikasi.

Kinerja usaha biasanya didefinisikan dengan membesarnya skala usaha yang dimilikinya, hal itu dapat dilihat dari volume produksi yang tadinya bisa menghabiskan sejumlah bahan baku perhari meningkat menjadi mampu mengolah bahan baku yang lebih banyak, serta bertambahnya karyawan (Haryadi, 1998).

Menurut Kasmir (2006:172), bahwa suatu keberhasilan atau kinerja usaha ditandai dengan peningkatan jumlah penjualan, meningkatnya jumlah produksi, meningkatnya keuntungan atau laba serta usaha yang selalu berkembang.

Menurut Saboet (1994:15), kriteria keberhasilan atau kinerja usaha meliputi adanya peningkatan volume produksi, adanya tambahan tenaga kerja, adanya tambahan alat produksi dengan berharap adanya peningkatan kemampuan produksi serta adanya tambahan modal yang berasal dari laba di tahan. Suryana (2014:285), mengemukakan kinerja usaha adalah kinerja dari bisnis dalam mencapai tujuannya yaitu dengan meningkatnya modal, pendapatan, volume penjualan, jumlah produksi dan tenaga kerja. Dapat disimpulkan bahwa kriteria kinerja usaha yang menjadi patokan atas penelitian ini, sebagai berikut:

1. Jumlah Karyawan

2. Peningkatan Omzet Penjualan

3. Peningkatan Outlet dan Pemasaran

4. Peningkatan Pengelolaan Usaha

\section{E. Hipotesis Penelitian}

Berdasarkan penelitian-penelitian yang telah dijelaskan sebelumnya, maka kerangka pikir penelitian dalam penelitian ini memiliki satu variabel independen dan satu variabel dependen dan dari penjelasan diatas timbul pertanyaan apakah penggunaan informasi akuntasi mempunyai pengaruh terhadap kinerja usaha. maka dirumuskan hipotesis yang akan diuji dalam penelitian ini:

$H_{o}$ : Tidak ada pengaruh penggunaan informasi akuntansi terhadap kinerja UMKM $H_{a}:$ Ada pengaruh penggunaan informasi akuntansi terhadap kinerja UMKM 
Jurnal Akuntansi dan Keuangan (JAK)

Volume 6, No. 2 Oktober Tahun 2021

Page: 243 - 256

http://ojs.uho.ac.id/index.php/jak-uho/issue/archive

e-ISSN: 2088-4656

\section{METODE PENELITIAN}

\section{A. Lokasi dan Objek Penelitian}

Lokasi penelitian ini berada di Kota Kendari. Sedangkan yang menjadi objek dari penelitian ini adalah penggunaan informasi akuntansi terhadap kinerja UMKM.

\section{B. Populasi dan Sampel Penelitian}

Populasi dalam penelitian ini adalah seluruh UMKM yang terdaftar di Dinas Perdagangan, Koperasi, dan UMKM yang bergerak di bidang fashion (pakaian jadi) sebanyak 100 pengusaha

Sampel penelitian ini diukur dengan menggunakan rumus slovin, sehingga didapatkan sampel sebanyak 50 pengusaha. Metode pengambilan sampel menggunakan purposive sampling dengan cara menentukan kriteria yang ditetapkan dalam pengambilan sampel pada penelitian ini adalah UMKM dalam bidang fashion yang sudah bergerak selama 2 tahun, memiliki karyawan lebih dari 1 orang.

\section{Jenis dan Sumber Data}

Jenis data yang digunakan dalam penelitian ini data kuantitatif berupa data primer dan data sekunder. Sumber data dalam penelitian ini adalah data primer diperoleh secara langsung oleh responden melalui penyebaran kuesioner Sedangkan data sekunder dalam penelitian ini adalah database yang diperoleh dari Dinas Perdagangan, Koperasi, dan UMKM Kota Kendari. Untuk sebagai data pendukung dalam penelitian ini.

\section{Metode Pengumpulan Data dan Metode Analisis Data}

Metode pengumpulan data dalam penelitian ini yaitu dengan menggunakan kuesioner. Skala pengukuran yang digunakan peneliti dalam penelitian ini yaitu skala likert. Metode analisis data yang digunakan yaitu statistik deskriptif, uji kualitas data, uji asumsi klasik, analisis regresi sederhana, dan uji hipotesis.

\section{HASIL DAN PEMBAHASAN}

\section{A. Hasil}

\section{Deskripsi Data}

Dari 50 kueisoner yang dibagikan kepada para pelaku UMKM selaku responden, semuanya dikembalikan dan dari 50 kuesioner tersebut datanya dapat diolah.

\section{Deskripsi Karakteristik Responden}

Karakteristik responden yang dimaksudkan dalam penelitian ini yaitu meliputi jenis kelamin, usia, pendidikan terakhir, lama usaha, dan omzet. Berdasarkan data yang didapatkan dari jawaban responden terhadap kuesioner yang dibagikan karakteristik responden sebagian besar memiliki jenis kelamin perempuan dengan presentase $62 \%$, usia sebagian besar memiliki usia 31-45 tahun dengan persentase 62\%, tingkat pendidikan terakhir sebagian besar memiliki tingkat pendidikan SMA dengan presentase $70 \%$, lama usaha sebagian besar memiliki lama usaha $>5$ tahun dengan presentase $78 \%$, dan omzet usaha sebagian besar memiliki omzet $>25$ Juta -50 Juta 
Jurnal Akuntansi dan Keuangan (JAK)

Volume 6, No. 2 Oktober Tahun 2021

Page: 243 - 256

http://ojs.uho.ac.id/index.php/jak-uho/issue/archive

e-ISSN: 2088-4656

dengan persentase $54 \%$.

\section{Deskripsi Data Variabel}

1. Penggunaan Informasi Akuntansi

Berdasarkan hasil tabulasi data dapat diketahui bahwa dari 17 item pernyataan, dapat diketahui bahwa jawaban responden sebagian besar pada jawaban Setuju $(20,2 \%)$ dan jawaban Sangat Setuju (6,84\%). Hal ini berarti secara umum responden cenderung memiliki respon yang baik terhadap informasi operasi, informasi manajemen, informasi akuntansi keuangan, Statutory Accounting Information, Budgetary Accounting Information, dan Additional Accounting Information.

2. Kinerja Usaha

Berdasarkan hasil tabulasi data dapat diketahui bahwa dari 14 item pernyataan, dapat diketahui bahwa jawaban responden sebagian besar pada jawaban Setuju $(16,48 \%)$ dan jawaban Sangat Setuju $(5,4 \%)$. Hal ini berarti secara umum responden cenderung memiliki respon yang baik terhadap Kinerja Usaha.

\section{B. Uji Kualitas Data}

\section{Uji Validitas}

Berdasarkan Uji Validitas dari semua item peryataan yang ada pada instrument penelitian ini baik item variabel penggunaan informasi akuntansi serta variabel kinerja usaha memiliki koefisien korelasi $\searrow 0,30$. Hal ini berarti semua item peryataan yang digunakan dalam penelitian ini adalah valid. Dengan demikian instrument dalam penelitian ini layak untuk dianalisis lebih lanjut.

\section{Uji Reliabilitas}

Berdasarkan hasil uji realibilitas menunjukkan nilai koefisien alpha dari keseluruhan item pernyataan yang dijadikan sebagai instrument masih berda di atas cut of value $\searrow 0,60$ berarti semua item yang dijadikan instrument dapat dipercayai keandalannya. Dari hal ini, dapat disimpulkan bahwa seluruh item pernyataan yang digunakan reliable, sehingga kuesioner yang digunakan dapat dikatakan layak dan dipercaya sebagai instrument untuk melakukan pengukuran setiap indikator variabel dan analisis data selanjutnya.

\section{Uji Asumsi Klasik}

\section{Uji Normalitas}

Dalam uji normalitas setelah data diolah menggunakan SPSS 22 diperoleh data menunjukkan bahwa terlihat titik plot yang dihasilkan menyebar di sekitar garis diagonal dan menyebar mengikuti arah garis diagonalnya, maka model regresi layak dipakai untuk prediksi penggunaan informasi akuntansi pada kinerja UMKM di Kota Kendari dan telah memenuhi asumsi normalitas.

\section{Uji Heteroskedastisitas}

Dalam uji heteroskedastisitas pada grafik scatter plot terlihat secara visual nilai residual dan nilai prediksinya tidak membentuk pola tertentu yang jelas dan tersebar di 
Jurnal Akuntansi dan Keuangan (JAK)

Volume 6, No. 2 Oktober Tahun 2021

Page: 243 - 256

http://ojs.uho.ac.id/index.php/jak-uho/issue/archive

e-ISSN: 2088-4656

bagian atas serta bagian bawah angka nol pada sumbu Y, sehingga dapat dikatakan bahwa model regresi dalam penelitian ini terbebas dari masalah heteroskedastisitas dan model ini layak digunakan untuk memprediksi variabel penggunaan informasi akuntansi berdasarkan masukan variabel independen kinerja usaha.

\section{Analisis Regresi Sederhana}

Regresi linier sederhana yaitu metode statistik untuk menguji hubungan antara variabel independen terhadap variabel dependen analisis ini bertujuan untuk menguji hubungan antar variabel penelitian, berikut adalah hasil analisis regresi sederhana:

\section{Coefficients $^{\text {a }}$}

\begin{tabular}{|c|c|c|c|c|c|}
\hline \multirow[t]{2}{*}{ Model } & \multicolumn{2}{|c|}{$\begin{array}{l}\text { Unstandardized } \\
\text { Coefficients }\end{array}$} & $\begin{array}{l}\text { Standardized } \\
\text { Coefficients }\end{array}$ & $\mathrm{t}$ & Sig. \\
\hline & B & Std. Error & Beta & & \\
\hline (Constant) & ,905 & ,399 & & 2,270 &, 028 \\
\hline $\begin{array}{l}\text { Penggunaan Informasi } \\
\text { Akuntansi }\end{array}$ & ,773 & 100 & ,746 & 7,768 & ,000 \\
\hline
\end{tabular}

a. Dependent Variable: Kinerja Usaha

Sumber : Data diolah (IBM SPSS, 22)

Berdasarkan hasil output SPSS 22 pada tabel diatas maka diketahui nilai constant (a) sebesar 0,905 dan nilai Penggunaan Informasi Akuntansi (b/ Koefisien regresi) sebesar 0,773 , sehingga persamaan sebagai berikut :

$\mathrm{Y}=0,905+0,773$

Hasil dari analisis tersebut dapat dijelaskan sebagai berikut :

1. Nilai konstanta sebesar 0,905 maka hal ini dapat dinyatakan bahwa apabila variabel penggunaan informasi akuntansi (X) adalah konstan (tidak berubah), maka kinerja usaha sebesar 0,905 .

2. Koefisien regresi $X$ sebesar 0,773 , maka hal ini dapat dinyatakan bahwa variabel penggunaan informasi akuntansi (X) memengaruhi kinerja usaha sebesar 0,773, artinya apabila setiap peningkatan variabel kinerja usaha sebesar satu satuan, maka akan meningkatkan penggunaan informasi akuntansi sebesar 0,773 dengan asumsi variabel yang lain tetap.

\section{E. Pengujian Hipotesis}

\section{Uji t $(t$-tes)}

Berdasarkan tabel ringkasan analisis regresi sederhana diperoleh t hitung 7,768. $\mathrm{T}$ tabel dicari pada signifikansi 0,025 dengan degree of freedom $=(\mathrm{Df}=\mathrm{n}-\mathrm{k})$ atau $\mathrm{Df}=$ 50-2 $=48$. Hasil diperoleh untuk $t$ tabel sebesar 2,01063. Karena t hitung $(7,768)>t$ tabel $(2,01068)$ sehingga dapat disimpulkan bahwa Penggunaan Informasi Akuntansi berpengaruh terhadap Kinerja Usaha Mikro, Kecil, dan Menengah. Berdasarkan tabel 4.9 diatas diperoleh tingkat signifikansi sebesar 0,000 . Karena tingkat signifikansi $<0,05$ $(0,000<0,05)$. Sehingga dapat disimpulkan bahwa Penggunaan Informasi Akuntansi 
Jurnal Akuntansi dan Keuangan (JAK)

Volume 6, No. 2 Oktober Tahun 2021

Page: 243 - 256

http://ojs.uho.ac.id/index.php/jak-uho/issue/archive

e-ISSN: 2088-4656

berpengearuh signifikan terhadap Kinerja Usaha Mikro, Kecil, dan Menengah. Dengan demikian Ha diterima dan $\mathrm{H}_{0}$ ditolak.

Uji Koefisien Determinasi $\left(R^{2}\right)$

\begin{tabular}{|l|r|r|r|r|}
\hline Model & $\mathrm{R}$ & \multicolumn{1}{|c|}{ R Square } & \multicolumn{1}{|c|}{$\begin{array}{c}\text { Adjusted R } \\
\text { Square }\end{array}$} & \multicolumn{2}{|c|}{$\begin{array}{c}\text { Std. Error of the } \\
\text { Estimate }\end{array}$} \\
\hline 1 &, $746^{\mathrm{a}}$ &, 557 &, 548 &, 26255 \\
\hline
\end{tabular}

a. Predictors: (Constant), Penggunaan Informasi Akuntansi

b. Dependent Variable: Kinerja Usaha

Sumber : Data diolah (IBM SPSS, 22)

Berdasarkan hasil dari tabel di atas, tampak bahwa dari hasil perhitungan diperoleh nilai koefisien determinasi $\left(\mathrm{R}^{2}\right)$ sebesar $0,746^{\mathrm{a}}$ yang berarti bahwa adanya pengaruh yang kuat antara variabel penggunaan informasi akuntansi terhadap kinerja usaha sebesar 74,6\%, bahwa pengaruh yang tergolong kuat adalah sebesar 0,60-0,79. Nilai R square atau koefisien determinasi sebesar 0,557 hal ini menunjukkan besaran kontribusi penggunaan informasi akuntansi (X) terhadap kinerja usaha (Y) adalah sebesar 55,7\% (kuat) dan sisanya sebesar $44,3 \%$.

\section{F. Pembahasan}

Penelitian menunjukkan bahwa variabel Penggunaan Informasi Akuntansi berpengaruh positif dan signifikan terhadap Kinerja Usaha. Hal ini berarti faktor Penggunaan Informasi Akuntansi yang diukur dengan mengetahui jumlah produksi setiap hari, mengetahui jumlah pembelian bahan baku, mengetahui jumlah pemakaian bahan baku, mengetahui penggajian/upah ke karyawan, mengetahui jumlah penjualan tiap harinya, merencanakan kegiatan usaha, mengimplementasikan/menjalankan usaha, mengendalikan usaha, mengetahui posisi keuangan, mengetahui kinerja perusahaan, mengetahui kenaikan atau penurunan modal, menggunakan informasi akuntansi yang sesuai dengan standar peraturan dari bank, koperasi Kota Kendari, akuntansi untuk menganggarkan usaha yang mendatang, dan menggunakan informasi akuntansi guna meningkatkan efektifitas pengambilan keputusan merupakan suatu faktor yang menentukan Kinerja Usaha pada UMKM di Kota Kendari.

Informasi akuntansi mempunyai pengaruh yang sangat penting bagi pencapaian kinerja usaha, termasuk UMKM. Dengan kurangnya pengetahuan dalam pembukuan, otomatis menghambat mereka menjalankan kegiatan pembukuan keuangan. Informasi akuntansi mempunyai pengaruh yang sangat penting bagi pencapaian kinerja UMKM.

Penggunaan informasi akuntansi yang berupa informasi operasi, informasi akuntansi manajemen dan informasi akuntansi keuangan dapat digunakan oleh pelaku UMKM untuk membantu dalam perencanaan usaha, mengontrol kegiatan usaha, pengambilan keputusan-keputusan dalam pengelolaan usaha, serta untuk melakukan evaluasi, 
Jurnal Akuntansi dan Keuangan (JAK)

Volume 6, No. 2 Oktober Tahun 2021

Page: 243 - 256

http://ojs.uho.ac.id/index.php/jak-uho/issue/archive

e-ISSN: 2088-4656

sehingga dengan melakukan hal tersebut dapat digunakan untuk menunjang keberhasilan usaha. Informasi akuntansi mempunyai pengaruh yang sangat penting bagi pencapaian keberhasilan usaha, termasuk usaha kecil. (Utomo, 2010).

Dikaitkan dengan penelitian ini, Stakeholder Theory relevan untuk menjelaskan penggunaan informasi akuntansi pada UMKM. Stakeholder memiki hak untuk mendapatkan informasi terkait aktifitas-aktifitas perusahaan yang mempengaruhi mereka. Semakin kuat hubungan stakeholder, maka akan semakin baik bisnis perusahaan. Tanpa dukungan dari pihak-pihak yang berkepentingan maka perusahaan tidak bisa hidup terus-menerus, oleh karena itu penggunaan informasi akuntansi pada perusahaan merupakan cara untuk mengelola kepercayaan pihak-pihak yang berkepentingan agar menghasilkan hubungan yang harmonis antara perusahaan dengan stakeholdernya. Informasi akuntansi yang cukup mengenai perubahan di masa lampau dan masa mendatang serta munculnya masalah dan persoalan sangat penting artinya bagi proses perencanaan perusahaan serta pengambilan keputusan. Semakin tinggi tingkat penggunaan informasi akuntansi, maka akan memotivasi pelaku bisnis untuk menyediakan informasi akuntansi yang sangat lengkap dan dalam. Penggunaan dari informasi akuntansi akan semakin meningkat seiring dengan semakin meningkatnya kemampuan pelaku bisnis dalam mengenali kebutuhan dalam dirinya, dengan mengenali karakteristik pribadinya yaitu faktor-faktor yang mungkin akan berpengaruh dalam pengambilan keputusan.

Informasi akuntansi yang berkualitas yang digunakan oleh pelaku usaha yang dapat digunakan untuk menunjang kinerja usaha. Hal tersebut dilakukan dengan membiasakan untuk mencatat setiap kegiatan usaha serta mengevaluasi setiap kegiatan keuangan usaha. Dengan menggunakan informasi akuntansi berupa catatan keuangan dengan baik akan dirasakan manfaatnya oleh UMKM, sehingga semua kegiatan usaha dapat terkontrol dengan baik. Dengan menggunakan sistem informasi akuntansi dalam pengelolaan usahanya, UMKM akan memperoleh Informasi yang lebih reliable sehingga dapat membantu dalam pengambilan keputusan yang tepat. Pengambilan keputusan yang tepat akan membantu UMKM untuk mencapai tujuan utamanya yaitu memaksimalkan labanya dan berpeluang besar dalam meningkatkan pertumbuhan modal sendiri. Problematika tersebut apabila diperkuat dengan pengambilan keputusan bisnis yang kurang tepat justru akan memperpuruk kondisi UMKM.

Informasi akuntansi yang rendah akan membawa dampak yang kurang baik dalam menjalankan usaha, seperti Statutory Accounting Information, merupakan informasi akuntansi yang sesuai dengan peraturan yang ada, informasi manajemen dalam hal ini pelaku usaha menggunakan informasi untuk merencanakan kegiatan usaha atau untuk mengendalikan usaha, Additional accounting information merupakan informasi akuntansi yang digunakan perusahaan untuk meningkatkan efektifitas pengambilan keputusan manajer.

Penelitian ini tidak sejalan dengan hasil penelitian yang dilakukan oleh Novia dan Sitti (2019), dalam penelitiannya diperoleh hasil yang menunjukkan bahwa informasi 
Jurnal Akuntansi dan Keuangan (JAK)

Volume 6, No. 2 Oktober Tahun 2021

Page: 243 - 256

http://ojs.uho.ac.id/index.php/jak-uho/issue/archive

e-ISSN: 2088-4656

akuntansi berpengaruh tidak signifikan terhadap Kinerja Usaha Mikro, Kecil, dan Menengah (UMKM). Dapat diartikan bahwa kurangnya persepsi owner dalam penggunaan informasi akuntansi menghambat berjalannya sistem informasi akuntansi tersebut sehingga kinerja usaha tidak mengalami peningkatan.

Penelitian ini sejalan dengan hasil penelitian yang dilakukan oleh Nurhikmah dan Djauhar (2019), T.Irzal dan Mulia (2019), Kadek dan I.G.N Agung (2014). Dalam penelitiannya diperoleh hasil yang menunjukkan bahwa Penggunaan Informasi Akuntansi berpengaruh positif dan signifikan terhadap Kinerja Usaha Mikro, Kecil, dan Menengah (UMKM). Dapat dijelaskan bahwa penggunaan informasi akuntansi yang mudah dipelajari, mudah dalam menyelesaikan pekerjaan, fleksibel dan memberikan ketergantungan pada kinerja usaha membuat pekerjaan karyawaan dapat memengaruhi kualitas karyawan. Hal ini menunjukkan semakin tinggi penggunaan informasi akuntansi maka kinerja usaha akan meningkat, sebaliknya jika penggunaan informasi akuntansi menurun maka kinerja usaha juga menurun.

\section{KESIMPULAN, IMPLIKASI, KETERBATASAN, REKOMENDASI}

\section{Kesimpulan}

Berdasarkan hasil penelitian dan pembahasan dapat ditarik kesimpulan bahwa Penggunaan Informasi Akuntansi berpengaruh signifikan terhadap Kinerja Usaha Mikro, Kecil, dan Menengah (UMKM) di Kota Kendari yang bergerak di sektor fashion (pakaian jadi). Hal ini terjadi karena variabel penggunaan informasi akuntansi mempunyai signifikansi yaitu t hitung lebih besar dari t tabel, sehingga dapat diartikan bahwa semakin tinggi penggunaan informasi akuntansi maka semakin meningkatnya kinerja usaha, sebaliknya jika penggunaan informasi akuntansi menurun maka kinerja usaha juga menurun.

\section{Implikasi}

Hasil penelitian ini diharapkan dapat memberikan masukan, bahan acuan dan dapat bermanfaat untuk sarana informasi tambahan terkait penggunaan informasi terhadap kinerja usaha mikro, kecil, dan menengah (UMKM).

\section{Keterbatasan}

Penelitian ini hanya menggunakan wilayah penelitian pada UMKM di Kota Kendari yang berada di sektor fashion (pakaian jadi), hendaknya penelitian selanjutnya dapat menambah beberapa sektor dan memperbanyak sampel penelitian. Penelitian ini juga terbatas pada satu variabel dependen saja yaitu kinerja usaha, diharapkan untuk peneliti selanjutnya menambah variabel dependen lainnya.

\section{Rekomendasi}

Peneliti memberikan saran dari jawaban responden yang di dapatkan bahwa ratarata skor yang paling rendah pada indikator penggunaan informasi akuntansi yaitu Statutory Accounting Information, informasi manajemen, Additional accounting information, bisa mengannti item pertanyaan yang mudah dipahami oleh pelaku usaha 
Jurnal Akuntansi dan Keuangan (JAK)

Volume 6, No. 2 Oktober Tahun 2021

Page: 243 - 256

http://ojs.uho.ac.id/index.php/jak-uho/issue/archive

e-ISSN: 2088-4656

sehingga lebih meningkatkan penggunaan informasi akuntansi dan juga dapat dilakukan pelatihan akuntansi terlebih dahulu. Pada variabel kinerja usaha yang paling rendah skornya yaitu outlet dan pemasaran sehingga perlu untuk meningkatkan pemasaran agar usaha dapat tetap stabil pengelolaannya. Maka dari itu diharapkan untuk peneliti selanjutnya dapat menambah item-item pertanyaan yang lain sehingga dapat menjadi bahan pertimbangan dalam mengukur variabel penggunaan informasi akuntansi.

\section{DAFTAR PUSTAKA}

Belkaoui, Riahi Ahmed. (2000). Teori Akuntansi. Edisi Pertama, Salemba Empat, Jakarta.

Dinas Perdagangan, Koperasi, dan UMKM. 2019.

Haryadi, Dedi; Erna Ermawati dan Maspiyati, (1998), Tahap Perkembangan Usaha Kecil, AKATIGA, Bandung.

Hall, James. A. (2009). Accounting Information System. Jakarta: Salemba Empat.

Holmes dan Nicholls. (1988). An analysis of the use of accounting information by Australian small business. Journal of Small Business Management. Vol.26 No.20: 57-68.

Indralesmana, Kadek Wahyu dan Suaryana, I.G.N. Agung. (2014), Penerapan Sistem Informasi Akuntansi Dan Kinerja individu Pada Usaha Kecil Dan Menengah Di Nusa Penida, EJurnal Akuntansi Universitas Udayana 7.2 (2014): 345-356

James, M. Reeve; Warren, Carl, S Warren dan Jonathan, E Duchac (2017). Pengantar Akuntansi 1, Edisi 4. Jakarta : Salemba Empat.

Kamus Besar Bahasa Indonesia (KBBI). https://kbbi.web.id/guna. Diakses 26 agustus $\underline{2020}$.

Kasmir. (2006). Kewirausahaan. Jakarta : PT.Raja Grafindo Persada.

Lestari, Novia Amanda. dan Rustiana, Siti Hamidah (2019). Pengaruh Persepsi Owner dan Pengetahuan Akuntansi Dalam Penggunaan Sistem Informasi Akuntansi Terhadap Kinerja Usaha Mikro, Kecil, dan Menengah di Pamulang. Journal od Business and Entrepreneurship Volume 1 No. 2 Bulan April Tahun 2019.

Mauliansyah, T.Irzal Rizki, dan Saputra, Mulia. (2019). Pengaruh Penerapan Sistem Informasi Akuntansi (SIA) Terhadap Kinerja Perusahaan (Studi Empiris Pada UMKM di Kota Banda Aceh). Jurnal Ilmiah Mahasiswa Ekonomi Akuntansi (JIMEKA). Vol 4 No. 4. Hal 602-612.

Prastika, Nurhikmah Esti. dan Purnomo, Djauhar Edi (2019). Pengaruh Sistem Informasi Akuntansi Terhadap Kinerja Perusahaa Pada Usaha Mikro, Kecil, dan Menengah (UMKM) di Kota Pekalongan. Jurnal Litbang. Kota Pekalongan.

Saboet. (1994). Pentingnya Informasi Akuntansi Dalam Kehidupan Manajemen, Majalah Ekonomi No. 11 - TH. 111- 1994.

Suwardjono. (2014). Teori Akuntansi Perekayasan Pelaporan Keuangan. Yogyakarta: BPFE-YOGYAKARTA. 
Jurnal Akuntansi dan Keuangan (JAK)

Volume 6, No. 2 Oktober Tahun 2021

Page: 243 - 256

http://ojs.uho.ac.id/index.php/jak-uho/issue/archive

e-ISSN: 2088-4656

Suryana (2014) 'Kewirausahaan Kiat Dan Proses Menuju Sukses', (edisi IV). Jakarta : Salemba Empat.

Tanjung, M. A. (2017). Koperasi dan UMKM. Jakarta: Erlangga.

Undang-Undang Republik Indonesia Nomor 20 Pasal 1 Tahun 2008 Tentang Usaha Miko, Kecil, dan Menengah. 